\title{
Leptin gene polymorphism in Boerawa and Peranakan Ettawa (PE) goats from South Sulawesi region
}

\author{
1Magfirah Nur, 'Lellah Rahim and ${ }^{2}$ Muhammad Ihsan Andi Dagong \\ 1Postgraduate of School Animal Science and Techonology, Faculty of Animal Science, Hasanuddin University, Makassar, South Sulawesi, Indonesia \\ ${ }^{2}$ Animal Production Department, Faculty of Animal Science, Hasanuddin University, Makassar, South Sulawesi, Indonesia
}

Correspondence Author: Magfirah Nur, Postgraduate of School Animal Science and Techonology, Faculty of Animal Science, Hasanuddin University, Makassar, South Sulawesi, Indonesia

Received date: 12 November 2018, Accepted date: 10 January 2019, Online date: 25 January 2019

Copyright: (C) 2019 Magfirah Nur et al., This is an open-access article distributed under the terms of the Creative Commons Attribution License, which permits unrestricted use, distribution, and reproduction in any medium, provided the original author and source are credited.

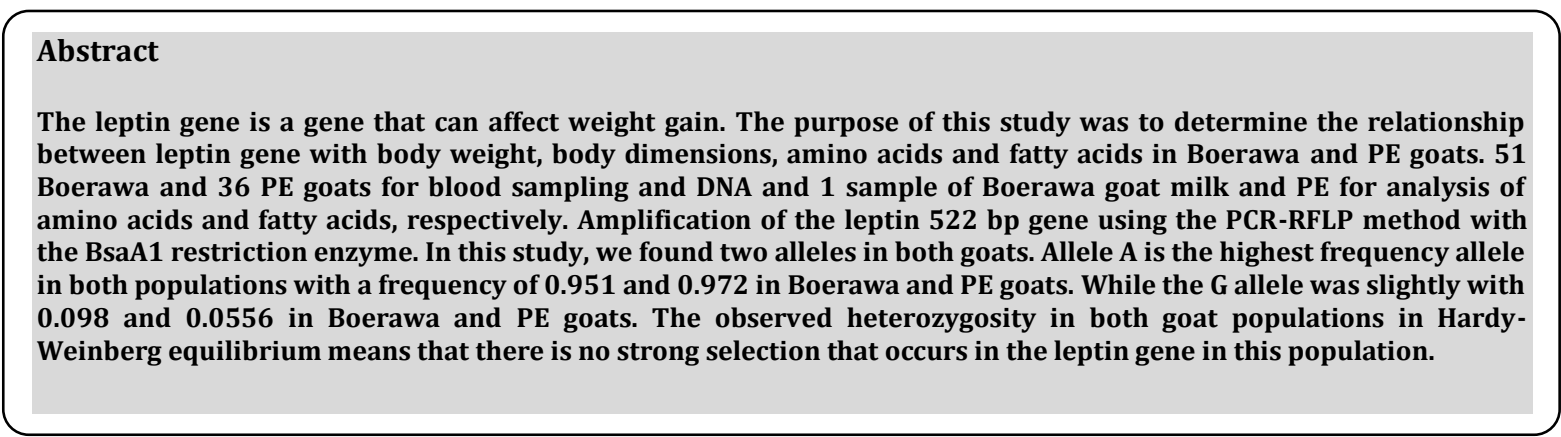

Keywords: Leptin gene, polymorphism, Boerawa and Peranakan Ettawa (PE) goats, South Sulawesi

\section{INTRODUCTION}

Boerawa and Peranakan Etawa (PE) goats are potential genetic resources to be developed and utilized as meat production. A crossbreeding between local female PE goat with male Boar goat [1] because has become the main component in many goat improvement programs [2] are a reasonable approach for targeting better performance and meat quality production [1]. A crossbreed goat between Boer and PE goats namely Boerawa which has advantages such as high growth of $0.17 \mathrm{~kg} / \mathrm{day}$ and good adaptability [3]. PE goat is one of the producers of animal protein whose maintenance can be directed at increasing milk production because it can produce milk as much as 1.5 - 3 liters every day [4].

Utilization of the genetic potential of local goats is one of the programs carried out by the Soppeng District Agricultural Service to improve the genetic quality of goats, especially the goats from the crossing of the Boer goat and the PE called Boerawa goats. It is known that Boer goats have rapid growth and PE goats that have a high level of adaptation and high milk production.

Genetic diversity information in particular of genes that control economical properties on the goat are needed to improve of the genetic quality and development of local goat [5]. The productivity of Boerawa and PE goats can be increased through efforts to improve genetic quality through growth. Growth is a trait that is controlled by many genes. One of the genes that influence the growth of goats is leptin.

The leptin gene functions to produce the hormone leptin synthesized from adipose tissue (fat) which then plays an important role in controlling body weight, feed consumption and energy balance [6]. Polymorphism in exon 3 intron 2 leptin genes was reported to occur in Nilagiri sheep [7] and Malpura sheep [8]. In addition, the leptin gene polymorphism is also associated with the nature of production in sheep [9] and is significant with the nature of growth in Kermani sheep [10].

The purpose of this study was to identify the diversity of the leptin gene in Boerawa goats and PE and is expected to be an information material in the genetic quality of Boerawa and PE goats.

\section{MATERIALS AND METHODS}

\section{Blood Sample Collection}

Blood samples were collected from 36 PE goats and 51 Boerawa goats from two regions in South Sulawesi, namely in the goat cage of the Soppeng District Agricultural Service Superior Breeding Plant and goat pens at the Hasanuddin University 
Faculty of Animal Science, Makassar. About $2 \mathrm{ml}$ of blood sample is taken through the jugular vein using a vacutainer tube with EDTA and then stored at $5^{\circ} \mathrm{C}$.

\section{DNA Extraction}

DNA was isolated and purified using an extraction DNA kit (gSYNCTM DNA Extraction Kit) by following the extraction protocol provided. The extracted DNA was collected and stored at $-20^{\circ} \mathrm{C}$ before being used for PCR.

\section{PCR-RFLP:}

Leptin gene fragments located in intron 2 - exon 3 were identified using PCR-RFLP (Restriction Fragment Length Polymorphism). Fragments are reinforced by primary sequences F: 5'-GTCTGGAGGCAAAGGGCAGAGT-3 'and R: 5'CCACCACCTCTGTGGAGTAG-3 by [11]. Amplification was carried out by PCR conditioned on a reaction volume of $25 \mu 1$ consisting of $100 \mathrm{ng}$ DNA, $0.25 \mathrm{mM}$ each primer, $150 \mu \mathrm{M}$ dNTP, $2.5 \mathrm{mM} \mathrm{Mg} 2+, 0.5 \mathrm{Taq}$ DNA polymerase and $1 \mathrm{x}$ buffer.

The PCR condition begins with initial denaturation at $94^{\circ} \mathrm{C}$ for 4 minutes, followed by 35 subsequent cycles each denaturing $94^{\circ} \mathrm{C}$ for 45 seconds, with annealing temperature of $60^{\circ} \mathrm{C}$ which then extends $72^{0} \mathrm{C}$ for 1 minute, then ends with one final extension cycle at $72^{0} \mathrm{C}$ for 5 minutes using the PCR machine. The PCR product was then electrophoresed on a $1.5 \%$ agarose gel visualized on a UV transiluminator. The PCR product is then cut using the BsaA1 restriction enzyme based on the protocol provided (Fermentas). The genotype of the RFLP product was then identified by electrophoresis on a $1.5 \%$ agarose gel with a $1 \mathrm{x}$ TBE buffer containing $200 \mathrm{ng} / \mathrm{ml}$ of ethidium bromide and visualized on a UV transiluminator.

\section{Statistic analysis}

Analysis of leptin molecular data in the population of PE and Boerawa goats including allele and genotype frequencies, Hardy-Weinberg balance, observation heterozygosity (Ho) and expectation heterozygosity (He) were calculated using Popgen32 software. Relationship between leptin gene genotype and body weight and body dimensions tested $t$.

\section{RESULTS AND DISCUSSION}

\section{Gen Characterization of the Boerawa and Peranakan Etawa (PE) Goat}

The results of the amplification of the leptin gene with the primer used were based on [11] in the intron region 2 exon 3 in Boerawa and PE goats analyzed by PCR (Polymerase Chain Reaction) machine visualized in agarose gels in picture 1.

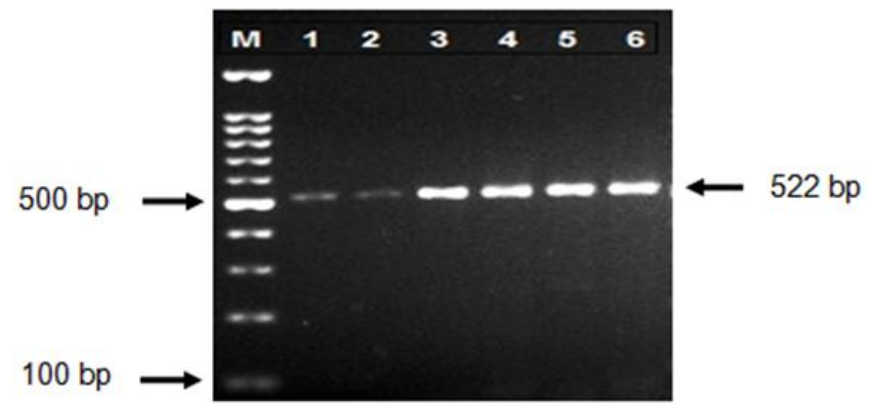

Figure 1. Results of leptin gene amplification on PCR machine, M: marker $100 \mathrm{bp}$; 1-3: samples of Boerawa goats; 4-6: PE goat samples; bp: base pair

The length of the fragment from the leptin gene amplification was obtained by $522 \mathrm{bp}$. This is consistent with the research of [11] and [12] that the fragment length found was $522 \mathrm{bp}$. The PCR products are then cut using the BsaAI restriction enzyme with the AC | GT cutoff position. The cutting results can be seen in Figure 2.

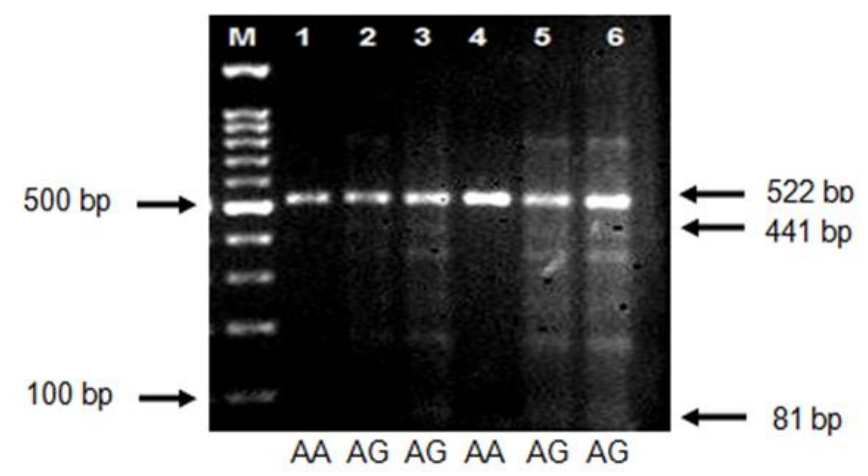

Figure 2. Visualization of PCR-RFLP with BsaAI enzyme, M: marker 100 bp; lanes 1-3: samples of Boerawa goats; lanes 4-6: PE goat samples; bp: base pair 
The results of cutting the PCR product measuring 522 bp produced A allele and G. Alel A all sized 552 bp and G allele measuring 81 bp. In Boerawa and PE goats two genotypes were obtained, namely AA and AG genotypes. In the AA genotype with one fragment $(522 \mathrm{bp}$ ) medium in the genotype AG with three fragments (552, 441 and $81 \mathrm{bp}$ ) (figure 2). This is similar to the findings of [12] who only found two genotypes (AA and AG) in Kacang goats.

The positioning of the primer leptin gene and cutting by the BsaAI enzyme can be seen in Figure 3.

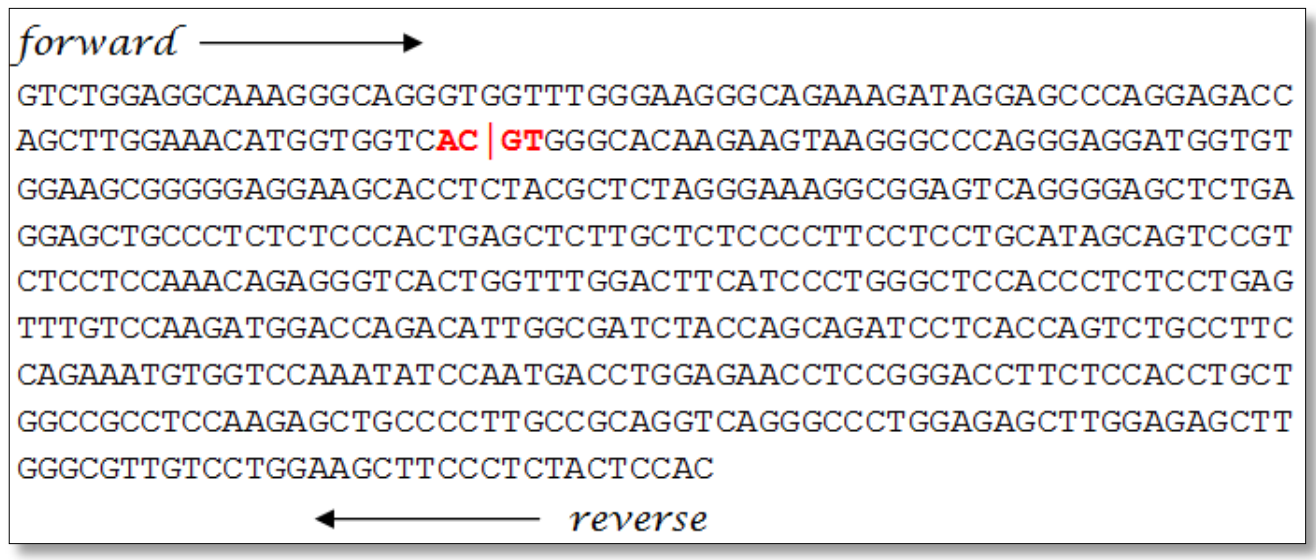

Figure 3. Position of primer attachment and cutting site of BsaAI enzyme

Cutting at the BsaAI locus occurs because of a mutation that causes the BsaAI enzyme to recognize the area as a cutting site. As a result, there is one cutting point of the BsaAI enzyme that produces two fragments. The mutation at this locus is estimated to be a transition mutation that causes a base change from Guanine $(G)$ to Adenine (A) substitution [12].

\section{Frequency of Alleles and Genotypes}

The results of frequency analysis of alleles and genotypes in the leptin gene can be seen in Table 1 .

Table 1. Frequency of alleles leptin genes

\begin{tabular}{|c|c|c|c|c|c|c|}
\hline \multirow{2}{*}{ Breed } & \multirow{2}{*}{ n } & \multicolumn{3}{|c|}{ Genotipe Frequency } & \multicolumn{2}{c|}{ Allele Frequency } \\
\cline { 3 - 7 } & & AA & AG & GG & A & G \\
\hline Boerawa & 28 & 0,902 & 0,098 & 0 & 0,951 & 0,049 \\
\hline Peranakan Etawa (PE) & 26 & 0,944 & 0,055 & 0 & 0,972 & 0,028 \\
\hline
\end{tabular}

Based on table data it can be seen that the genotyping frequency of the leptin gene in Boerawa goats is higher in the AA genotype $(0,902)$ than the genotype AG $(0,098)$ while the GG genotype is not found, as well as the PE goat genotype AA $(0,944)$ than AG $(0,055)$. This condition is like that of [12] that AA genotype frequency $(0,86)$ in Kacang goats is higher than genotype AG $(0,14)$ while GG genotype is not found.

\section{Observation Heterozygosity Value (Ho) and Hope Heterozygosity (HE)}

The results of the analysis of the value of observed heterozygosity (Ho) and expectation heterozygosity (He) of the leptin gene in Boerawa and PE goats can be seen in Table 2.

Table 2. Value of observation heterozygosity (Ho), expectation heterozygosity (He) and Hardy-Weinberg Equilibrium (HWE)

\begin{tabular}{|c|c|c|c|}
\hline \multirow{2}{*}{ Breed } & \multicolumn{2}{|c|}{ Heterozygosity Value } & \multirow{2}{*}{$\mathbf{X}^{\mathbf{2}}$ (HWE) } \\
\cline { 2 - 3 } & $\mathbf{H}_{\mathbf{0}}$ & $\mathbf{H}_{\mathbf{e}}$ & \\
\hline Boer & 0,0714 & 0,0701 & 0,019 \\
\hline Peranakan Etawa (PE) & 0,0769 & 0,0754 & 0,020 \\
\hline
\end{tabular}

Based on the data in Table 2 that the value of the observed heterozygosity (Ho) and the expected heterozygosity (He) of the leptin gene in both types of goats did not differ greatly. This condition indicates that the genotypic frequency of the two goat populations is in equilibrium. [13] also found something similar to this study, namely the Ho and He value for Makoei sheep was not much different. According to [14] which states that if there is a large difference between the value of observational heterozygosity (Ho) and expectation heterozygosity (He), it can be used as an indicator of genotypic imbalance in the observed population. The values of Ho and He are characteristic of high and low gene variations in the population. The higher the value of heterozygosity observed, the higher the diversity in a population. Conversely, the lower the value of heterozygosity observation the lower the diversity in a population. 


\section{Hardy Weinberg (HWE) Balance Value}

Testing Hardy-Weinberg equilibrium in the goat population Boerawa and Peranakan Etawa (PE) was performed using chisquare test that can be seen in Table 2 . The chi-square value in both populations goat $(0.1074$ and 0.015$)$ greater than 0.05 (figure significantly limit) so that it can be said that the goat population studied Boerawa and PE showed Hardy-Weinberg equilibrium. According to [15], that a population is said to be in Hardy-Weinberg equilibrium that is if the frequency of the genotype and allele frequencies remain constant from one generation to the next. Hardy Weinberg's imbalance occurs due to selection, unbalanced gene migration (migration), unbalanced mutations and random marriages [16].

\section{Relation of Genotype of Leptin Gene to Body Weight and Body Dimensions of Boerawa Goat and PE}

The average body weight and body dimensions in Boerawa goats and PE based on the leptin gene genotype can be seen in table 3 .

Table 3. Average body weight and dimensions of Boerawa and PE goat body with leptin gel genotype

\begin{tabular}{|c|c|c|c|c|}
\hline \multirow{2}{*}{ Body Dimension } & \multicolumn{2}{|c|}{ Boerawa Goat } & \multicolumn{2}{c|}{ PE Goat } \\
\cline { 2 - 5 } & Genotype AA & Genotype AG & Genotype AA & Genotype AG \\
\hline & & & & \\
Body weight $(\mathrm{kg})$ & $48,58 \pm 10,83$ & $55,00 \pm 2,83$ & $38,40 \pm 5,63$ & $41,00 \pm 5,66$ \\
Chest circumference $(\mathrm{cm})$ & $80,08 \pm 5,96$ & $86,00 \pm 0,00$ & $75,52 \pm 3,19$ & $78,00 \pm 2,83$ \\
Body length $(\mathrm{cm})$ & $75,00 \pm 6,06$ & $79,00 \pm 4,24$ & $72,48 \pm 5,20$ & $78,50 \pm 10,61$ \\
Body height $(\mathrm{cm})$ & $66,56 \pm 4,78$ & $68,50 \pm 3,54$ & $70,81 \pm 4,18$ & $71,50 \pm 2,12$ \\
\hline
\end{tabular}

Based on Table 3, we can find the results of body weight and body dimensions (chest circumference, body length and body height) in the AG genotype higher than AA genotypes in both Boerawa and PE goats. The same is shown in the study of [17] which obtained average body dimensions (chest circumference, body length and height) Cashmere goats with AB genotype higher than $\mathrm{AA}$ and $\mathrm{BB}$ genotypes.

\section{CONCLUSION}

Leptin gene diversity in Boerawa dan Peranakan Etawa (PE) goat identified found two type of allele (A and G) with two genotypes AA and AG. The A allele was the most common alleles in Boerawa and PE goats. AG genotype is higher than AA genotype which is associated with body weight and body dimensions.

\section{ACKNOWLEDGEMENT}

The research was supported by Hasanuddin University institute of research and community services and authors thank to Soppeng District Agricultural Service Superior Breeding Installation

\section{REFERENCES}

1. Ciptadi, G., A. Budiarto, M. N. Ihsan, U. Wisaptiningsih and S. Wahyuningsih. 2014. Reproductive performance and successof artificial inseminasion in Indonesian crossbreed goats in research versus small holder farm. American-Eurasian Journal of Sustainaible Agriculture. 8(7): $35-38$.

2. Salama, R., M. I. Mohamed, S. Abd-Allah, R. I. El-Kady, A. I. Kadry and M. M. $\quad$ Mabrouk. $2015 . \quad$ Improving the productive performance of local Baladi goats throughout crossbreeding with South African Boer. Advanges in Environmental Biology. 9(27): $224-231$.

3. Directorate of Animal Development. 2004. Report on intensification of Goat Livestock Business in Lampung Province. http://www.disnakkeswan- lampung.go.id/publikasi/bplm. Accessed on October 14, 2018.

4. Setiawan, A. I. 2002. Ettawa Livestock Dairy Goat Breeding. Penebar Swadaya. Jakarta.

5. Dagong, M. I. A., S. R. A. Bugiwati and K. I. Prahesti. 2016. Genetic polymorphism of pituitary specific transcription factor 1 (Pit-1) gene from Indonesian local goat population reared in South Sulawesi province. Advanges in Environmental Biology. 10(5): $121-125$.

6. Fruhbeck, G., S. A. Jebb and A. M. Prentice. 1998. Leptin: Physiology and Pathophysiol. J. Clin. Physiol. $18: 399$ - 419.

7. Cauveri, D., S. N. Sivaselvam, S. M. K. Karthickeyan, K.G. Tirumurugaan and K. Kumanan. 2014. Allelic polymorphism of exon 3 of leptin gene in Nilagiri sheep identified by sequencing and PCR-RFLP. International Journal of Science Environment and Technology. 3 : 951 - 955. American-Eurasian Network for Scientific Information Journal. 10 (5): 121 125

8. Meena, A. S., R. S. Bhatt, A. Sahoo and S. Kumar. Polymorphism of the exon 3 of leptin gene in Malpura sheep. Indian J. Anim. Res. 51 (3): 469 - 473.

9. Boucher, D., M. F. Palin, F. Castonguay, C. Gariepy and F. Pothier. 2006. Detection of polymorphisms in the ovine leptin (LEP) gene: Association of a single nucleotide polymorphism with muscle growth and meat quality traits. Canadian Journal of Animal Sciences. 86: $31-35$. 
10. Shojaei, M., M. M. Abadi, M. A. Fozi, O. Dayani, A. Khezri and M. Akhondi. 2010. Association of growth trait and leptin gene polymorphism in Kermani sheep. Journal of Cell and Moleculer Research. 2: $67-73$.

11. Choudhary, V., P. Kumar, T. K. Bhattacharya, B. Bhushan and A. Sharma. 2005. DNA polymorphism of leptin gene in Bos indicus and Bos taurus cattle. Genetics and Moleculer Biology. 28: 740 - 742.

12. Syarifulaya, N., M. Sriasih and Maskur. 2015. Identification of the diversity of leptin genes in bali cattle and Kacang goat. Journal of Indonesian Animal Science and Technology. 1 (1): 40 - 46.

13. Hashemi, A., K. Mardani, M. Farhadian, I. Ashrafi and M. Ranjbari. 2011. Allelic polymorphism of Makoei sheep leptin gene identified by polymerase chain reaction and single strand conformation polymorphism. Afr. J. Biotechnol. 10 (77): 17903 17906.

14. Tambasco, D. D., C. C. P. Paz, M. Tambasco-Studart, A. P. Pereira, M. M. Alencar, A. Freitas, L. L. Countinho, I. Packer and L. Regitano. 2003. Candidate genes for growth traits in beef cattle Bos Taurus x Bos Indicus. J. Anim. Bred. Genet. 120: $51-60$

15. Vasconcellos, L. P. M. K., D. T. Talhari, A. P. Pereira, L. L. Coutinho, and L. C. A. Regitano. 2003. Genetic Characterization of Arberdeen Angus cattle using molecular markers. J. Genet. Mol. Biol. 26: 133 - 137.

16. Aryulina, C. Muslim, S. Manaf, and E. Winarni. 2006. Biology 3. Erlangga. Jakarta.

17. Ziaaldini, M., E. Sanjari, A. Esmaelizadeh and M. mohammadabadi. 2017. Association of leptin gene polymorphism with body size in Raeini cashmere goats. 9 (2): $97-109$. 